\title{
Roles of microRNAs in abdominal aortic aneurysm pathogenesis and the possibility of their use as biomarkers
}

\author{
Adam Borek, Franciszek Drzymała, Malwina Botor, Aleksandra M. Auguściak-Duma, Aleksander L Sieroń \\ Department of Molecular Biology, Faculty of Medical Sciences in Katowice, Medical University of Silesia, Katowice, Poland
}

Kardiochir Torakochir Pol 2019; 16 (3): 124-127

\begin{abstract}
Abdominal aortic aneurysm (AAA) is a dangerous condition involving pathological dilation of the aortic wall. Due to the asymptomatic course of this disease and the dangerous consequences of its rupture, it is important to identify its specific bio-markers expressed as early as possible. Different expression profiles of microRNAs (miRNAs) were detected in patients diagnosed with AAA. MicroRNAs are small non-coding RNA molecules that regulate the expression of other genes at the translation stage. miRNAs affecting translation can lead to abnormal remodeling of extracellular matrix, inhibition of the cell cycle, cell aging or intensified inflammation. This review summarizes current knowledge about the role of microRNAs in the context of formation and development of abdominal aorta aneurysm and the possibility of using some miRNAs as biomarkers, and also provides basic information about miRNAs and aneurysms.
\end{abstract}

Key words: miRNA, inflammation, matrix metalloproteinases.

\section{Introduction}

An abdominal aortic aneurysm (AAA) is an enlargement of the aortic diameter above $30 \mathrm{~mm}$ [1]. While in 2005 around 134000 people died worldwide due to aortic aneurysms, this number increased to 168000 in 2015. Thus, in only 10 years, the number of people dying of aortic aneurysm increased by nearly $25 \%$ [2]. Factors increasing the risk of disease are older age, male gender (among men it is six times more common than in women), smoking, blood clots, hypertension, atherosclerosis and genetic defects $[3,4]$. AAA accounts for $70 \%$ to $90 \%$ of aortic aneurysms and is most often located below the renal arteries. AAA is extremely dangerous because of its asymptomatic development and when the symptoms are not specific. For example, patients report abdominal or lumbar pain [1]. In the case of a sudden aneurysm rupture $70 \%$ of patients die

\section{Streszczenie}

Tętniak aorty brzusznej (AAA) jest groźnym schorzeniem polegającym na poszerzeniu ściany aorty. Ze względu na bezobjawowy przebieg AAA oraz niebezpieczne skutki jego pęknięcia ważne jest znalezienie swoistych bioznaczników (biomarkers) tego schorzenia. U osób ze zdiagnozowanym AAA wykryto inny profil ekspresji genów kodujących miRNA. Są to małe cząsteczki niekodującego RNA, które regulują ekspresję innych genów na etapie translacji. miRNA, wpływając na translację, mogą prowadzić do nieprawidłowej przebudowy macierzy zewnątrzkomórkowej, hamowania cyklu komórkowego, przyspieszenia starzenia się komórek oraz przyspieszać rozwój stanu zapalnego. W artykule podsumowano obecną wiedzę na temat roli mikroRNA w powstawaniu tętniaka, możliwości wykorzystania niektórych miRNA jako bioznaczników, a także przedstawiono podstawowe informacje o miRNA i tętniakach.

Słowa kluczowe: miRNA, stan zapalny, metaloproteinazy macierzy pozakomórkowej.

before reaching the hospital, and among those who have reached the hospital half of them die. The total mortality rate of such cases is around $80 \%$. The quoted data show how important early detection of AAA is. The results of ultrasound examination of AAA showed that such screening tests, conducted among men between 65 and 74 years of age, allow for early intervention, which leads to a decrease in mortality due to AAA rupture [5].

Numerous reports of research data indicate that small microRNAs play an important role in the development of AAA and may in the future be used in laboratory tests as indicators of the presence of an aneurysm. Currently, there is no non-invasive simple test, such as a blood test, that allows for the diagnosis of AAA. This review presents current knowledge on the pathogenesis of AAA with particular emphasis on the role of miRNA [6-8]. 


\section{Histological structure of the aorta and classification of aneurysms}

The aorta is an elastic type of artery, which is evidenced by the presence of numerous elastic plaques in its tissue structure. In the aortic wall three general layers are distinguished: the inner membrane, the widest layer, which is the middle membrane, and the external membrane (adventitia). The inner membrane is composed of a single layer of endothelial cells that rest on the basal membrane. Its outer limit is the inner elastic membrane. The middle membrane contains numerous, concentrically arranged elastic structures, made of elastic fibers. There are collagen fibers and smooth muscle myocytes that produce the components of the extracellular matrix (ECM) between the laminae. The additional membrane is composed mainly of collagen fibers and contains vessels that nourish the deeper layers of the arterial blood vessel by diffusion [9].

Two general types of AAA at this point should be distinguished, the real, delaminating and purulent aneurysms. In real aneurysms, despite the dilatation, the continuity of all walls is preserved. Delaminating aneurysms arise as a result of damage to the inner membrane and blood penetration between the aortic layers, resulting in their stratification. Pseudoaneurysm ussually arise as a result of penetrating injury and involves only two outer layers of artery: tunica media and tunica adventitia. Their wall is formed of the outer membrane or the connective tissue bag covered with a thrombus [10].

\section{Pathogenesis of abdominal aortic aneurysm}

The pathogenesis of AAA is complex and has not been yet fully understood. Nevertheless, several significant factors have been identified in its development. These include chronic inflammation, death of smooth myocytes and degradation of the extracellular matrix. Leukocytes penetrate all the aortic wall layers and secrete numerous molecules there, including antibodies, cytokines, leukotrienes and reactive oxygen species, such as superoxide anion $\left(\mathrm{O}_{2}{ }^{-}\right)$. In the middle and accessory membranes, macrophages are the most numerous group of the immune system cells. Macrophages, fibroblasts, smooth muscle myocytes and endothelial cells can produce and secrete matrix metalloproteinases (MMPs), as well as serine and cysteine proteases. These proteolytic enzymes faster hydrolyze ECM proteins, such as elastin or collagens type I and III, whose half-life under physiological conditions is around 70 years. A characteristic feature of AAA is also a significant decrease in the number of smooth muscle myocytes in the median membrane [11, 12]. If the aneurysm is not treated, its constant enlargement and progressive weakening of the vessel wall leads to aortic rupture, which in most cases results in death. As the size of the aneurysm increases, the risk of its rupture also increases [1].

\section{Origin, structure and miRNA function}

miRNA is a group of non-coding, single-stranded RNA molecules with a length of about 22 nucleotides, found in cells, both plants and animals. The miRNA function is post-transcriptional regulation of gene expression. To date, more than 1900 different types of miRNAs have been identified in humans [13, 14]. The results of numerous published studies indicated that in humans over $60 \%$ of genes encoding proteins are regulated by miRNAs [15]. miRNA arises as the original miRNA transcript (primary miRNA - primiRNA), which has the structure of several connected hairpins. primiRNA is synthesized by RNA polymerase II, on a template of deoxyribonucleic acid (DNA) encoding one or several miRNAs. As a result of the Drosha nuclease activity, primiRNA is cut and shortened at both ends of the strand and so precursor miRNA (premiRNA) is formed. The premiRNA forming a stem loop intermediate of around 60 to 70 nucleotides is then transported from the nucleus to the cytoplasm by exportin-5 (Exp5) in the nuclear pore complexes (NPCs) [16]. In the cytoplasm, it is further processed by the transactivation response element RNA binding region (TRBP) nuclease complexed with Dicer. The resulting miRNA is a 21 to 22 nucleotide molecule. Due to the incorporation of one of the two strands of miRNA into the RNA-induced silencing complex (RISC), a mature functional miRNA molecule is formed that interacts with the mRNA in one of three ways. First, it can combine with mRNA on the basis of full complementarity with the non-translated sequence at the $3^{\prime}$ end of the mRNA ( $3^{\prime} \cup T R$ ). After this combination, the translation is suppressed as a result of the mRNA's nucleolytic degradation. Another possible interaction of miRNA with mRNA leads to poly $(A)$ tail degradation, which destabilizes the mRNA. The third option is to combine the miRNA with mRNA on the basis of incomplete complementarity, leading to the breakdown of the mRNA complex with the ribosome and termination of biosynthesis of the protein encoded by the mRNA $[17,18]$. Therefore, miRNAs play significant roles in many pathological processes, including in cardiovascular diseases such as hypertension, heart defects, coronary heart disease, cardiac arrhythmia, atherosclerosis and cancer $[19,20]$.

\section{The role of miRNA in the pathogenesis of AAA}

It is known that some miRNAs play roles in the development of the aneurysm. For example, the miR-29 family comprises miR-29a, miR-29b and miR-29c involved in reducing the expression of genes encoding extracellular matrix proteins such as elastin (ELN), collagen types I and III and fibrillin 1. The results of the studies described by Boon et al. showed that the concentration of miR-29 in the aortic tissue of older mice was higher than that in young mice. Elevated miR-29 expression led to ECM degradation, resulting in a weakened aortic wall, making it susceptible to aneurysm development. In another study, the use of the miR-29 inhibitor prevented the development of an aneurysm in aged mice [21]. Another microRNA, miR-205, reduced the biosynthesis of tissue inhibitor of metalloproteinase 3 (TIMP3), which is a glycoprotein that binds to the catalytic domain of MMPs. These enzymes are proteases that specifically hydrolyze the components of ECM. miR-205 reduced 
the intensity of synthesis of reversion-inducing cystine-rich protein with kazal motifs (RECK). RECK proteins are glycoproteins anchored in the cell membrane that inhibit metalloproteinases [22, 23].

\section{microRNAs as bio-markers}

Patients with AAA are usually affected by numerous other diseases such as hypertension, atherosclerosis, etc. These diseases have their distinctive miRNA expression profiles. In order to accurately identify miRNAs specific to the aneurysm and ignore the miRNAs appearing in other diseases, it is necessary to select the appropriate control group with diseases coexisting with AAA [4, 19]. The first studies aimed at verifying the possibility of using miRNA present in the patient's blood as a bio-marker of AAA were carried out by Zhang et al. Three miRNAs were selected, the expression of which was the most elevated relative to the control group. These were successively miR-191-3p, miR-455-3p and miR-1281 [24]. Interestingly, these molecules were not previously associated with the development of AAA. Elevated miR-191 concentration was detected in aging human keratinocytes, where it was responsible for limiting cell proliferation. The function of miR-191 is to reduce the expression of genes encoding specific adenine and thymine-rich binding protein 1 (SATB1) proteins and cyclin-dependent kinase 6 (CDK6). The SATB1 protein binds specifically to the DNA sequence rich in adenine-thymine pairs. It is located in the cell nucleus and is responsible for regulating the chromatin rearrangement, which affects the expression of genes. CDK6 is an important component of the complex necessary for transition from the G1 phase to the S phase of the cell cycle. Decreased expression of this protein causes inhibition of cell cycle progression, which results in the onset of the aging process [25]. The results of investigations of human colon carcinoma cells (HCT116) revealed that miR-455-3p inhibited their proliferation and increased apoptosis in them [7]. However, the authors of this study pointed out that the results of these studies should not be overestimated due to the fact that the studied group was relatively small, as it consisted of 70 people, 10 of whom participated in the first stage of the study and 60 in the second stage. In addition, they were not consistent with other studies and therefore, to confirm the data, additional studies should be carried out on larger groups of participants [24].

Tenorio et al. carried out research which only partly confirmed the results obtained by Zhang et al., because they did not investigate the expression of miR-1281. In this study, the patients with AAA had the blood collected prior to intravascular aneurysm repair and then 6 months after the surgery. The intensity of miR-191 and miR-455-3p expression, 6 months after removal of AAA, was lower than prior to the procedure. No association was found between the intensity of miRNA expression and the size of the aneurysm [26]. Studies by Maegdefessel et al. showed that the intensity of miR-24 expression in AAA tissues was weaker. miR-24 is associated with reduction of the synthesis of chi- tinase 3-like protein 1 (CHI-3L1). In the study the growth of human aortic smooth myocytes was stimulated with interleukin-6 (IL-6), which resulted in a decrease in miR-24 concentration and, as a result, elevated expression of CHI3L1. CHI3L1 cooperating with IL-6 contributed to the increase in the production of pro-inflammatory factors such as monocyte chemoattractant protein 1 (MCP1), interleukin 8 (IL-8) and increased migration of smooth myocytes. CHI3L1 and IL-6 also affected human aortic endothelial cells by stimulating them to produce adhesion molecules, such as vascular cell adhesion molecule (VCAM1), intercellular adhesion molecule 1 (ICAM1) and P-selectin (P-SELP), which could lead to binding of leukocytes to the surface of the endothelium. The results of miR-24 and CHI3L1 in the blood of patients with AAA revealed a smaller amount of miR-24, while the amount of CHI3L1 was higher compared to the control group. In addition, a correlation was observed between CHI3L1 concentration and the size of the aneurysm. The obtained results indicate that miR-24 and CHI3L1 could be used in the diagnosis of AAA [8].

Sanak et al. have shown that also the presence of miR$29 c-3 p$ in the patient's blood could be used as an indicator of the presence of AAA. The concentration of miR-29c-3p in the blood of patients with AAA was higher than in the control group. In addition, these researchers found a relationship between the size of the aneurysm and the intensity of expression of miR-29c-3p. However, no relationship was found between the amount of miR-29c-3p and the factors that increase the risk of aneurysm, such as gender, age, hypertension or hypercholesterolemia. From the pool of genes regulated by miR-29c-3p, four characteristic for endothelial cells were selected, whose decreased expression could contribute to the formation of an aneurysm. These were the genes encoding ELN, collagen type IV, and phosphatase and tensin homolog (PTEN), which inhibits cell proliferation. Among these genes, there was also a gene coding for vascular endothelial growth factor-A (VEGF A), which is essential for endothelium survival. VEGF A stimulates endothelial cells to proliferate and migrate, and also helps to maintain homeostasis under stress conditions. Its deficiency leads to the fragmentation of mitochondria, suppression of glucose metabolism and, consequently, endothelial autophagy. Expression of these genes in human endothelial cells decreased after miR-29c-3p transfection, and increased after the addition of anti-miR-29c-3p [6, 9].

\section{Conclusions}

AAA is a disease affecting mostly men over 65 years of age. There are numerous common risk factors associated with it, such as smoking, hypertension and atherosclerosis. This disease is often asymptomatic and if left untreated it usually leads to rupture of the aneurysm and the person's death. The pathogenesis of AAA is complex. Numerous published research papers indicate that inflammation of the aortic wall, extracellular matrix degradation and the death of smooth muscle myocytes play the key roles. All the factors are regulated by the corresponding miRNAs. Screening 
tests carried out in people with an increased risk of disease allow the mortality rate to be reduced. Despite the possibility of detecting AAA by ultrasound, bio-markers may in future supplement or even displace this method due to their simplicity, specificity and availability. However, it should be noted that the use of miRNAs as AAA bio-markers requires additional studies, to be carried out on sufficiently large risk groups and appropriately selected reference groups.

\section{Disclosure}

The authors report no conflict of interest.

\section{References}

1. Pasierski T. Choroby tętnicy głównej. In: Interna. Januszewicz W, Kokot F (eds). PZWL, Warsaw 2006; 275-281.

2. Global, regional, and national life expectancy, all-cause mortality, and causespecific mortality for 249 causes of death, 1980-2015: a systematic analysis for the Global Burden of Disease Study 2015. Lancet 2016; 10053: 1459-1544.

3. Scott RAP, Bridgewater SG, Ashton HA. Randomized clinical trial of screening for abdominal aortic aneurysm in women. Br J Surg 2002; 89: 283-285.

4. Karwowska A, Kurianiuk A, Łapiński R, Gacko M, Karczewski J. Epidemiology of abdominal aortic aneurysm. Prog Health Sci 2015; 5: 238-245.

5. Ashton HA, Buxton MJ, Day NE, Kim LG, Marteau TM, Scott RA, Thompson SG, Walker NM. Multicentre Aneurysm Screening Study Group, The Multicentre Aneurysm Screening Study (MASS) into the effect of abdominal aortic aneurysm screening on mortality in men: a randomised controlled trial. Lancet 2002; 9345: 1531-1539.

6. Lichołai S, Szczeklik W, Sanak M. miR-29c-3p is an effective biomarker of abdominal aortic aneurysm in patients undergoing elective surgery. MicroRNA 2016; 5: 124-131.

7. Zheng J, Lin Z, Zhang L, Chen H. MicroRNA-455-3p inhibits tumor cell proliferation and induces apoptosis in hct116 human colon cancer cells. Med Sci Monit 2016; 22: 4431-4437.

8. Maegdefessel L, Spin JM, Raaz U, Eken SM, Toh R, Azuma J, Adam M, Nagakami F, Heymann HM, Chernugobova E, Jin H, Roy J, Hultgren R, Caidahl K, Schrepfer S, Hamsten A, Eriksson P, McConnell MV, Dalman RL, Tsaoa PS. miR-24 limits aortic vascular inflammation and murine abdominal aneurysm development. Nature Commun 2014; 5: 5214.

9. Malejczyk J, Sawicki W. Histologia. PWN, Warsaw 2014.
10. Wiechowski S, Listewnik M. Serce. In: Chirurgia. Podręcznik dla studentów. Noszczyk W (ed). PZWL, Warsaw 2009; 542-548.

11. Davis FM, Rateri DL, Daugherty A. Abdominal aortic aneurysm: novel mechanisms and therapies. Curr Opin Cardiol 2015; 30: 566-573.

12. Shimizu K, Mitchell RN, Libby P. Inflammation and cellular immune responses in abdominal aortic aneurysms. Arterioscler Thromb Vasc Biol 2006; 26: 987-994.

13. Bartel DP. MicroRNAs: genomics, biogenesis, mechanism, and function. Cell 2004; 116: 281-297.

14. http://www.mirbase.org/cgi-bin/mirna summary.pl?org=hsa (online: 13.08.2018).

15. Friedman RC, Farh KK, Burge CB, Bartel DP. Most mammalian mRNAs are conserved targets of microRNAs. Genome Res 2009; 19: 92-105.

16. Yi R, Doehle BP, Qin Y, Macara IG, Cullen BR. Overexpression of exportin 5 enhances RNA interference mediated by short hairpin RNAs and microRNAs. RNA 2005; 11: 220-226.

17. Weil PA. Synteza, przekształcanie i metabolim RNA. In: Biochemia Harpera. Rodwell VW, Bender DA, Botham KM (eds). PZWL, Warsaw 2018; 495-518.

18. Brown TA. Genomy. PWN, Warsaw 2013.

19. Romaine SP, Tomaszewski M, Condorelli G, Samani NJ. MicroRNAs in cardiovascular disease: an introduction for clinicians. Heart 2015; 101: 921-928.

20. Chen X, Ba Y, Ma L, Cai X, Yin Y, Wang K, Guo J, Zhang Y, Chen J, Guo X, Li Q Li X, Wang W, Zhang Y, Wang J, Jiang X, Xiang Y, Xu C, Zheng P, Zhang J, Li R, Zhang H, Shang X, Gong T, Ning G, Wang J, Zen K, Zhang J, Zhang CY. Characterization of microRNAs in serum: a novel class of biomarkers for diagnosis of cancer and other diseases. Cell Res 2008; 18: 997-1006.

21. Boon RA, Seeger T, Heydt S, Fischer A, Hergenreider E, Horrevoets AJG, Vinciguerra M, Rosenthal N, Sciacca S, Pilato M, van Heijningen P, Essers J, Brandes RP, Zeiher AM, Dimmeler S. MicroRNA-29 in aortic dilation: implications for aneurysm formation. Circ Res 2011; 109: 1115-1119.

22. Kim CW, Kumar S, Son DJ, Jang $I H$, Griendling KK, Jo H. Prevention of abdominal aortic aneurysm by anti-microRNA-712 or anti-microRNA-205 in angiotensin II-infused mice. Arterioscler Thromb Vasc Biol 2014; 34: 1412-1421.

23. Jung P, Zimowska M. Metaloproteinazy macierzy zewnątrzkomórkowej w rozwoju, fizjologii i procesach degeneracyjnych mięśni szkieletowych. Postep Biochem 2016; 62: 353-362.

24. Zhang W, Shang T, Huang C, Yu T, Liu C, Qiao T, Huang D, Liu Z, Liu C. Plasma microRNAs serve as potential biomarkers for abdominal aortic aneurysm. Clin Biochem 2015; 15: 988-992.

25. Lena AM, Mancini M, Rivetti di Val Cervo P, Saintigny G, Mahé C, Melino G, Candi E. MicroRNA-191 triggers keratinocytes senescence by SATB1 and CDK6 downregulation. Biochem Biophys Res Commun 2012; 423: 509-514.

26. Tenorio EJR., Braga AFF, Tirapelli DPDC, Ribeiro MS, Piccinato CE, Joviliano EE. Expression in whole blood samples of miRNA-191 and miRNA-455-3p in patients with aaa and their relationship to clinical outcomes after endovascular repair. Ann Vasc Surg 2018; 50: 209-217. 